ISSN 1678-3921

Journal homepage: www.embrapa.br/pab

For manuscript submission and journal contents, access: www.scielo.br/pab

\section{Soil chemical properties in vineyard areas in the southern region of the state of Santa Catarina, Brazil}

\begin{abstract}
The objective of this work was to evaluate changes in the soil chemical properties and the critical environmental limit for phosphorus (CEL-P) in vineyards, in the southern region of the state of Santa Catarina, Brazil. Soil samples were collected at $0-5,5-10,10-20$, and $20-40 \mathrm{~cm}$ soil depths, in vineyards aged 22, 36, and 60 years, and in the area of an adjacent native forest. The following parameters were analyzed: granulometry, $\mathrm{pH}$ in water, and exchangeable $\mathrm{Al}$ levels, to obtain potential acidity and $\mathrm{Al}$ saturation; and available levels of $\mathrm{P}$ and $\mathrm{K}$, and exchangeable levels of $\mathrm{Ca}$ and $\mathrm{Mg}$, to determine base saturation, cation exchange capacity; and soil organic matter (SOM). In comparison with the forest soil, the vineyard soils showed increased $\mathrm{pH}$ values, $\mathrm{P}, \mathrm{K}, \mathrm{Ca}, \mathrm{Mg}, \mathrm{Cu}, \mathrm{Zn}$, and $\mathrm{SOM}$ levels, and base saturation, as well reduced $\mathrm{Al}$ saturation, with more accentuated effects in areas with the longest cultivation time. The vineyards show changes in soil chemical properties with time and P levels above the CEL-P, at least in one of the soil layers.
\end{abstract}

Index terms: Vitis, heavy metals, phosphorus, soil acidity, vine.

\section{Atributos químicos do solo em áreas de vinhedos na região sul do estado de Santa Catarina}

Resumo - O objetivo deste trabalho foi avaliar alterações nas propriedades químicas do solo e o limite crítico ambiental para o fósforo (LCA-P), em vinhedos da região sul do estado de Santa Catarina, Brasil. Amostras de solo foram coletadas às profundidades do solo $0-5,5-10,10-20$ e $20-40$ $\mathrm{cm}$, em vinhedos com 22, 36 e 60 anos de idade, e em uma área de mata nativa adjacente utilizada como referência. Os seguintes parâmetros foram analisados: granulometria, $\mathrm{pH}$ em água, e teores trocáveis de Al, para cálculo de acidez potencial e saturação por Al; e teores disponíveis de $\mathrm{P}$ e $\mathrm{K}$ e teores trocáveis de $\mathrm{Ca}$ e $\mathrm{Mg}$, para determinação de saturação por bases, capacidade de troca de cátions e matéria orgânica do solo (MOS). Em comparação ao solo da mata, os solos dos vinhedos apresentaram aumento nos valores de $\mathrm{pH}$, nos níveis de $\mathrm{P}, \mathrm{K}, \mathrm{Ca}, \mathrm{Mg}, \mathrm{Cu}, \mathrm{Zn}$ e MOS, e na saturação por bases, além de redução na saturação de $\mathrm{Al}$, com efeitos mais acentuados nas áreas com maior tempo de cultivo. Os vinhedos da região sul de Santa Catarina apresentam alterações nas propriedades químicas do solo, com o tempo, e teores de $\mathrm{P}$ acima do LCA-P, pelo menos em uma das camadas do solo.

Termos de indexação: Vitis, metais pesados, fósforo, acidez do solo, videira. 


\section{Introduction}

Southern Brazil has the largest grapevine area in the whole country, and the states of Rio Grande do Sul (RS) and Santa Catarina (SC) are responsible for approximately $68 \%$ of the national grape production. Most soils are acidic and have low natural fertility, therefore, acidity correctives and fertilizers are applied to the soil before planting and throughout the grape production.

The official recommendations of liming and fertilization for vine growing - such as those proposed by the Soil Chemistry and Fertility Commission (Manual..., 2016) for Rio Grande do Sul and Santa Catarina - are not always followed. Thus, soil acidity correctives are sometimes applied either at excessive doses or below the plant requirements, and they are not homogeneously incorporated into the soil. Thereby, when the use of limestone doses is lower than those recommended, and the incorporation is not homogeneously performed in the soil diagnostic layer, soil $\mathrm{pH}$ values do not reach the recommended ones for grapes, which should be higher than 6.0 (Manual..., 2016). In addition, it does not increase the calcium (Ca) and magnesium $(\mathrm{Mg})$ contents to adequate levels, reflecting lower base saturation values, highly toxic $\mathrm{Al}^{+3}$ and $\mathrm{Al}$ saturation values, which can cause $\mathrm{Al}$ toxicity to grapes or cover plants in vineyards.

Potassium (K) and phosphate (P) fertilizers, especially in pre-planting fertilization and production, are sometimes applied above the need of the vine (Schmitt et al., 2014). Therefore, increases of P and $\mathrm{K}$ can be expected in the soil profile because of the saturation of the functional groups of soil reactive particles, especially in sandy soils with low soil organic matter (SOM), which is the case of the vineyards in the southern region of Santa Catarina. In the case of $\mathrm{P}$, its soil contamination potential can be measured by the critical environmental limit for P (CEL-P) (Gatiboni et al., 2014), and its limit values in vineyard soils in southern Brazil have not been known so far.

In general, in the vineyard areas, cover plants are planted in the lines and between lines of the grapes, which increases the addition of organic residues on the soil surface and, consequently, improves the carbon stock in the soil (Paustian et al., 2016). With the maintenance or increment of SOM levels, mainly in degraded vineyard soils, a greater availability of $\mathrm{N}$ is expected for grapes and cover plants, as well as of $\mathrm{Al}^{+3}$ complexation and the increase of the soil cation exchange capacity (CEC) (Priori et al., 2018). Moreover, vineyards in southern Brazil are subjected to the continuous use of fungicides based on $\mathrm{Cu}$ and $\mathrm{Zn}$, for the preventive control of foliar fungal diseases, especially the mildew (Brunetto et al., 2017), and this management can increase the complexation, or adsorption of the elements (Girotto et al., 2016; Tiecher et al., 2016, 2017), reducing the potential of water transfer to the surface and groundwater adjacent to the vineyards (Brunetto et al., 2014, 2017).

The objective of this work was to evaluate changes in the soil chemical properties and the critical environmental limit for CEL-P in vineyards, in the southern region of the state of Santa Catarina, Brazil..

\section{Materials and Methods}

The vineyards used in the present study are located in the municipality of Urussanga $\left(28^{\circ} 31^{\prime} 04^{\prime \prime} \mathrm{S}\right.$, $49^{\circ} 19^{\prime} 15^{\prime \prime} \mathrm{W}$, at $49 \mathrm{~m}$ altitude), in the state of Santa Catarina, southern Brazil. The soil of the area was classified as Cambissolo Húmico (Santos et al., 2018), or Inceptisol according to Soil Survey Staff (1999). The climate of the region is Cfa type, mesothermic moist, with no defined dry season and with hot summers, according to the Köppen-Geiger's classification. The annual average temperature is $19.2^{\circ} \mathrm{C}$, and the rainfall of $1,540 \mathrm{~mm}$ per year.

The selected areas for the study had the following land use history at the collection time: vineyard with 22 years, with first planting in 1995 and eradication in 2010, and the second in 2012 (V22); vineyard with 36 years, with the first planting in 1981, and eradication in 2004, and the second in 2006 (V36); vineyard with 60 years with a single planting (V60); and a native forest area (NF), as reference, which was about 100 , $250,2,300 \mathrm{~m}$ away from the V22, V36, and V60, respectively.

According to the granulometric analysis, the areas NF, V22, V36, and V60 showed, respectively, 303, 321, 349, and $319 \mathrm{~g} \mathrm{~kg}^{-1}$ clay; 578, 516, 489, and 434 $\mathrm{g} \mathrm{kg}^{-1}$ sand; and 119, 163, 162, and $246 \mathrm{~g} \mathrm{~kg}^{-1}$ silt. The predominance of the sand fraction influences the reactivity of soils, especially with elements such as $\mathrm{P}$ and heavy metals, limiting the capacity of these soils to receive applications of these elements. 
The grape cultivars in V22 and V36 was 'Niágara Rosa', and in V60, it was 'Goethe', both grafted on 'Paulsen' rootstock and conducted in the trellising system.

The plant spacing in the three vineyards was $1.5 \times 3.0 \mathrm{~m}$, with 2,400 plants ha- ${ }^{-1}$. In the V22 and V36 vineyards, ryegrass (Lolium multiflorum) and turnip (Brassica rapa L.) were cultivated as winter cover crops, while spontaneous plants prevailed in the summer season, such as the southern crabgrass (Digitaria ciliaris), the gallant soldier or potato weed (Galinsoga spp.), and the bitter dock (Rumex obtusifolius). The V60 vineyard had rare spontaneous plants in the whole year. The vegetation between the lines was usually mown on September of each year, and the residue was deposited on the soil, while the vegetation of the line was desiccated with nonresidual herbicide, also on September of each year. The branches of pruning in the winter and senescent leaves were kept on the ground over the years in the three vineyards.

The vineyard areas received limestone use (PRNT $=85 \%)$ to raise the soil $\mathrm{pH}$ water to approximately 6.0. Limestone for V22 was applied in 2010, after the eradication of the first planting and before the second one. In V36, two limestone applications were carried out, the first one in 1985, and the second one in 2005, after the eradication of the first vineyard and before the second planting of the vines. The limestone was applied to the soil surface and incorporated up to about $20 \mathrm{~cm}$ soil depth. In the V60, about five superficial applications of limestone were carried out during the 60 years of cultivation. In addition, the periodic use of fertilizers are carried out for all areas of vineyards, using a conventional management according to the cultural practices foreseen for the crop. The application of fungicides and syrup were carried out over the years for the control of foliar fungal diseases. The products, doses, and number of annual average use accomplished in each vineyard area are presented (Table 1).

In August 2017, samples of soil were collected at $0-5$, 5-10, 10-20, and 20-40 cm soil depths. The samples were collected in three trenches of $30 \times 30 \times 40 \mathrm{~cm}$, randomly opened in the rows of the cultivation on each of the areas (V22, V36, V60, and M). The soil samples were air-dried, ground, and passed through a $2 \mathrm{~mm}$ sieve to obtain the air-dried soil fraction. The following physical and chemical parameters were determined: sand, silt, and clay composition, by the pipette method (Claessen, 1997); $\mathrm{pH}$ in water (ratio 1:1); SMP index and exchangeable levels of $\mathrm{Al}$ obtained from these data were used to determine the acidity potential $(\mathrm{H}+\mathrm{Al})$ and $\mathrm{Al}$ saturation (Al\%) (Manual..., 2016); available contents of $\mathrm{P}$ and $\mathrm{K}$ (extracted by Mehlich 1); exchangeable levels of $\mathrm{Ca}$ and $\mathrm{Mg}$ (extracted by $\mathrm{KCl} 1$ mol L-1), according to Tedesco et al. (1995); total organic carbon (TOC) levels, with subsequent transformation in the SOM contents (Claessen, 1997), from which the base saturation $(\mathrm{V} \%)$ and potential cation exchange capacity $\left(\mathrm{CEC}_{\mathrm{pH} 7.0}\right)$ were calculated (Manual..., 2016). In addition, the available contents of $\mathrm{Cu}$ and $\mathrm{Zn}$ were determined through Mehlich 1 extraction.

The $\mathrm{P}$ content was determined by colorimetry (Murphy \& Riley, 1958), in the Ultraviolet-visible Spectroscopy (NI 1600UV, Novainstruments, Piracicaba, SP, Brazil). The levels of $\mathrm{K}$ were determined by flame photometer (DM-62, Digimed, São Paulo, SP, Brazil). Al values were found by titration with $\mathrm{NaOH} 0.0125 \mathrm{~mol} \mathrm{~L}^{-1}$. The contents of $\mathrm{Ca}, \mathrm{Mg}$, $\mathrm{Cu}$, and $\mathrm{Zn}$ were exposed to the atomic absorption spectrophotometer.

Table 1. Chemical products, doses, and number of foliar applications to the vineyards 22 (V22), 36 (V36), and 60 (V60), in the southern region of Santa Catarina state, Brazil.

\begin{tabular}{lcccc}
\hline Vineyard area & Product & Composition & Dose ha ${ }^{-1}$ & Application per year \\
\hline V22/V36/V60 & Roundup & $\mathrm{C}_{3} \mathrm{H}_{8} \mathrm{NO}_{5} \mathrm{P}$ & $2.0 \mathrm{~L}$ & 1 \\
V22/V36 & Thiophanate methyl & $\mathrm{C}_{12} \mathrm{H}_{14} \mathrm{~N}_{4} \mathrm{O}_{4} \mathrm{~S}_{2}$ & $0.4 \mathrm{~kg}$ & 4 \\
V22/V36 & Chlorothalonil & $\mathrm{C}_{8} \mathrm{Cl}_{4} \mathrm{~N}_{2}$ & $1.0 \mathrm{~kg}$ & 4 \\
V22/V36 & Aliette & $\mathrm{C}_{6} \mathrm{H}_{18} \mathrm{AlO}_{9} \mathrm{P}_{3}$ & $2.5 \mathrm{~L}$ & 3 \\
V22/V36 & Mancozeb & $\left(\mathrm{C}_{4} \mathrm{H}_{6} \mathrm{~N}_{2} \mathrm{~S}_{4} \mathrm{Mn}\right) \times \mathrm{XZ}$ & $2.4 \mathrm{~kg}$ & 3 \\
V22/V36 & Tebuconazole & $\mathrm{C}_{16} \mathrm{H}_{22} \mathrm{ClN}_{3} \mathrm{O}$ & $0.25 \mathrm{~L}$ & 3 \\
V60 & Bordeaux mixture & $\mathrm{CuSO}_{4}+\mathrm{CaO}$ & $750 \mathrm{~L}$ & Undetermined \\
\hline
\end{tabular}

History of chemical product applications provided by Mr. Emilio Dela Bruna, of the Empresa de Pesquisa Agropecuária e Extensão Rural de Santa Catarina (Epagri), in the municipality of Urussanga, in the state of Santa Catarina, Brazil. 
After the granulometric (sand, silt, and clay composition) analysis, the clay levels were used as a basis for later calculation of the critical environmental limit of $\mathrm{P}$ (CEL-P) for the vineyard areas with the equation CEL-P $\left(\mathrm{mg} \mathrm{dm}^{-3}\right)=40+\%$ clay (Gatiboni et al., 2014).

To compare data between areas and detect differences, the obtained variances should be subjected to the maximum F-test. If homogeneous, they meet the assumptions of normality and homoscedasticity, and can be continued with the analysis of variance, at $95 \%$ significance. If there is an interaction between factors and variables for cause and effect relationship, the Tukey's at 95\% significance should be performed between the areas and between the depths. The parameters without significant differences should be removed from the models.

\section{Results and Discussion}

The evaluated soil chemical properties showed differences between the vineyard areas (Table 2). For soil $\mathrm{pH}$, V60 showed the highest values in all layers, while NF and V22 showed the lowest values and did not differ from each other, except for the 5-10 cm layer. The soils of southern Brazil are naturally acidic, and most vineyards are sensitive to soils with high levels of acidity. Thus, it is possible to assign the lowest $\mathrm{pH}$ values observed in the NF area to the processes of natural acidification of the soils of the region, while in the vineyard soils, the limestone was applied to raise the $\mathrm{pH}$ up to 6.0 (Manual..., 2016).

The vineyard areas showed higher $\mathrm{pH}$ values (up to $20 \mathrm{~cm}$ soil depth) than the control area, especially in the areas V36 and V60, which can be justified by the limestone application and subsequent incorporation into the soil in the V36, and migration of limestone and organic compounds in the V60. It is important to note that the last limestone application to V36 was performed in the incorporated form, up to $20 \mathrm{~cm}$ soil depth, which justifies higher $\mathrm{pH}$ values at this layer, with a decrease at $20-40 \mathrm{~cm}$ soil depths. In the V60, the acidity correctives were already made on the surface, without incorporation and, in this area, the $\mathrm{pH}$ values were higher than 5.5 in all the evaluated layers. According to Kaminski et al. (2005), when limestone is incorporated into the soil, the effects are restricted to the incorporated layer. However, when the use is superficial, without soil revolving, the maintenance of biopores favors the percolation of water-soluble organic compounds, and the displacement of anions results from the limestone hydrolysis and the migration of fine limestone particles, allowing of the neutralization action of the acidity in depth.

In the V22 area, the $\mathrm{pH}$ values like those observed in the NF area indicate that liming performed in 2010 could neither be efficient to raise $\mathrm{pH}$ up to 6.0 nor maintain it for a long period. All the V22 layers had a $\mathrm{pH}$ value lower than 5.5, which is an indicative of $\mathrm{Al}^{+3}$ levels in the soil that are potentially toxic to plants. The presence of this chemical element in the soil solution can cause toxicity to grapes and covering plants, affecting their growth and, consequently, the nutrient cycling and soil protection (Vieira et al., 2009).

The highest values of potential acidity $(\mathrm{H}+\mathrm{Al})$ were observed up to $20 \mathrm{~cm}$ soil depth in the NF area, and from $5 \mathrm{~cm}$ soil depth, in the V22 area (Table 2). The values of $\mathrm{H}+\mathrm{Al}$ in the V36 and V60 areas did not differ for depths. This higher potential acidity observed in the $\mathrm{NF}$ and V22 areas may be related to the low $\mathrm{pH}$ values, as well as to the presence of $\mathrm{Al}$, since $\mathrm{Al}$ saturation was higher in these areas, mainly in the layers below 5 $\mathrm{cm}$ of soil depth. This fact explains the direct relation between soil acidity increases and the increasing $\mathrm{Al}^{3+}$ in the soil solution, reaching levels that affect the developments of the plant root system and the aerial part. According to the Manual... (2016), Al saturation values above $10 \%$ may cause damage to plants.

The available $P$ contents were higher at $0-5 \mathrm{~cm}$ soil depths than in the deeper layers in the vineyards areas, and V36 showed the highest $\mathrm{P}$ values (Figure $1 \mathrm{~A}$ ). These results may be explained by the high adsorption capacity of $\mathrm{P}$, in adsorption sites of inorganic particles in the soil, that reduces the mobility of these particles in the soil profile (Tokura et al., 2011). In addition, the use of nutrient sources in the vineyard areas was carried out on the surface, without incorporation, to avoid the mechanical damage to grape roots. Furthermore, residue of soil cover and senescent leaves, deposited over the years on the soil surface, contributed also to the cycling and maintenance of higher levels of nutrients, such as $\mathrm{P}$, at the soil surface (Lehmann et al., 2016). The NF area showed the lowest values of $\mathrm{P}$ for all the evaluated layers which had a smaller variation along the soil profile in relation to the cultivated areas which received fertilization with high 
rates of phosphate fertilizers, to meet the requirements of the vine culture over the years. Besides, the increase of $\mathrm{pH}$ caused by liming generates negative charges due to the deprotonation of hydroxyls exposed in the clay and SOM, resulting in the repulsion of $\mathrm{PO}_{4}^{-3}$ from the particle surface, consequently increasing the availability of this nutrient in the soil solution (McBride, 1994).

All the vineyard areas showed high $\mathrm{P}$ levels to grapes, up to $20 \mathrm{~cm}$ soil depth, indicating that there is excess $P$ in the soil (Manual..., 2016). In part, this can be explained by the high doses of phosphate fertilizers use, which are usually above the crop needs (Schmitt et al., 2014), or it would be explained by the small P amounts exported by the grape through the bunches that were bigger than the accumulated amounts of $\mathrm{Ca}$, $\mathrm{Mg}$, S, and micronutrients only (Tecchio et al., 2007).

The high pollutant potential of $P$ in agricultural areas can be transferred to water sources through surface runoff and percolation (Girotto et al., 2013; Lourenzi et al., 2015). Thus, proposed levels to indicate the critical environmental limit for P (CEL-P) for Santa Catarina state Gatiboni et al. (2014). Applying the equation established by the authors to the vineyard areas, the mean value of $72.9 \mathrm{mg} \mathrm{kg}^{-1}$ (extracted by Mehlich-1) was observed as a CEL-P. This way, it is possible to verify that, except for the NF area, all other areas showed $\mathrm{P}$ levels above the CEL in at least one of the evaluated layers (Figure $1 \mathrm{~A}$ ), indicating that they are areas with high potential of environmental contamination. Therefore, the adoption of practices that minimize $\mathrm{P}$ transfers to water sources is indicated, such as the use of soil cover plants and the suspension of phosphate fertilizer use in these areas (Sharpley, 2016).

The highest available $\mathrm{K}$ contents were observed at $0-5 \mathrm{~cm}$ soil depths in V22 and V36, while the NF area showed the lowest contents in all evaluated layers (Figure 1 B). This can be attributed to the application of $\mathrm{K}$ fertilizers in the vineyards during the pre-planting fertilization and grape production (Ciotta et al., 2016). In addition, the deposition of residue of cover crops, leaves of grapes, and roots of these plants contribute to the cycling and maintenance of $\mathrm{K}$ in more superficial layers of the soil (Lehmann et al., 2016). Associated with this fact, $\mathrm{K}$ is the nutrient most exported by grape bunches, together with $\mathrm{N}$ (Tecchio et al., 2007). Moreover, smaller amounts of $\mathrm{K}$ may have migrated into the soil profile, which explains, in part, the lower levels of $\mathrm{K}$ in depth. The $\mathrm{K}$ contents at $20 \mathrm{~cm}$ soil depth were interpreted as "low" in NF, and "high" in

Table 2. Values of $\mathrm{pH}$ in water, potential acidity $(\mathrm{H}+\mathrm{Al})$, and aluminum saturation (Al\%) in soils of vineyard and native forest, in the southern region of Santa Catarina state, Brazil ${ }^{(1)}$.

\begin{tabular}{|c|c|c|c|c|c|}
\hline \multirow{2}{*}{$\begin{array}{l}\text { Soil depths } \\
\text { (cm) }\end{array}$} & \multicolumn{4}{|c|}{ Vineyard and native forest soils } & \multirow{2}{*}{$\begin{array}{l}\text { CV } \\
(\%)\end{array}$} \\
\hline & $\mathrm{NF}$ & V22 & V36 & V60 & \\
\hline \multicolumn{6}{|c|}{$\mathrm{pH}$ water } \\
\hline $0-5$ & $4.90 \mathrm{aC}$ & $5.13 \mathrm{aC}$ & $5.60 \mathrm{aB}$ & $6.11 \mathrm{cA}$ & 3.18 \\
\hline $5-10$ & $4.52 \mathrm{bD}$ & $4.85 \mathrm{baC}$ & $5.49 \mathrm{aB}$ & $6.33 \mathrm{aA}$ & 1.88 \\
\hline $10-20$ & $4.63 \mathrm{bC}$ & $4.66 \mathrm{baC}$ & $5.53 \mathrm{aB}$ & $6.24 \mathrm{bA}$ & 1.03 \\
\hline $20-40$ & $4.61 \mathrm{bC}$ & $4.50 \mathrm{bC}$ & $5.22 \mathrm{bB}$ & $5.95 \mathrm{dA}$ & 0.83 \\
\hline CV (\%) & 1.28 & 3.95 & 1.18 & 0.54 & - \\
\hline \multicolumn{6}{|c|}{$\mathrm{H}+\mathrm{Al}\left(\mathrm{cmol}_{\mathrm{c}} \mathrm{dm}^{-3}\right)$} \\
\hline $0-5$ & $5.66 \mathrm{cA}$ & $4.13 \mathrm{bCB}$ & $5.02 \mathrm{aAB}$ & $3.64 \mathrm{aC}$ & 11.18 \\
\hline $5-10$ & $8.50 \mathrm{aAB}$ & $10.44 \mathrm{baA}$ & $5.52 \mathrm{aBC}$ & $3.16 \mathrm{aC}$ & 16.86 \\
\hline $10-20$ & $6.86 \mathrm{bAB}$ & $12.82 \mathrm{aA}$ & $4.99 \mathrm{aB}$ & $2.86 \mathrm{aB}$ & 33.90 \\
\hline $20-40$ & $6.82 \mathrm{bB}$ & $13.17 \mathrm{aA}$ & $4.67 \mathrm{aB}$ & $3.34 \mathrm{aB}$ & 9.80 \\
\hline CV (\%) & 5.96 & 26.27 & 7.42 & 11.22 & - \\
\hline \multicolumn{6}{|c|}{ Aluminum saturation (Al\%) } \\
\hline $0-5$ & $10.58 \mathrm{bA}$ & $2.45 \mathrm{~dB}$ & $1.58 \mathrm{bB}$ & $0.80 \mathrm{aB}$ & 22.35 \\
\hline $5-10$ & $60.00 \mathrm{aA}$ & $27.77 \mathrm{cB}$ & $2.83 \mathrm{bC}$ & $0.64 \mathrm{aC}$ & 20.60 \\
\hline $10-20$ & $67.16 \mathrm{aA}$ & $52.33 \mathrm{bB}$ & $2.49 \mathrm{bC}$ & $0.70 \mathrm{aC}$ & 11.62 \\
\hline $20-40$ & $68.05 \mathrm{aA}$ & $75.22 \mathrm{aA}$ & $9.24 \mathrm{aB}$ & $0.97 \mathrm{aB}$ & 11.22 \\
\hline CV (\%) & 8.48 & 14.59 & 33.49 & 29.11 & - \\
\hline
\end{tabular}


the vineyard areas (Manual..., 2016), indicating that $\mathrm{K}$ fertilization in these areas is adequate.

The highest levels of $\mathrm{Ca}$ and $\mathrm{Mg}$ were observed at $0-5 \mathrm{~cm}$ soil depths of V36 (Figure $1 \mathrm{C}$ and D). In the other layers, the highest levels of $\mathrm{Ca}$ and $\mathrm{Mg}$ were verified in V60. These results are attributed to the history of limestone use in the two areas along the cycle of the vines. Although V22 also received a limestone application, it may not have been enough to raise $\mathrm{Ca}$ and $\mathrm{Mg}$ levels in the soil. According to
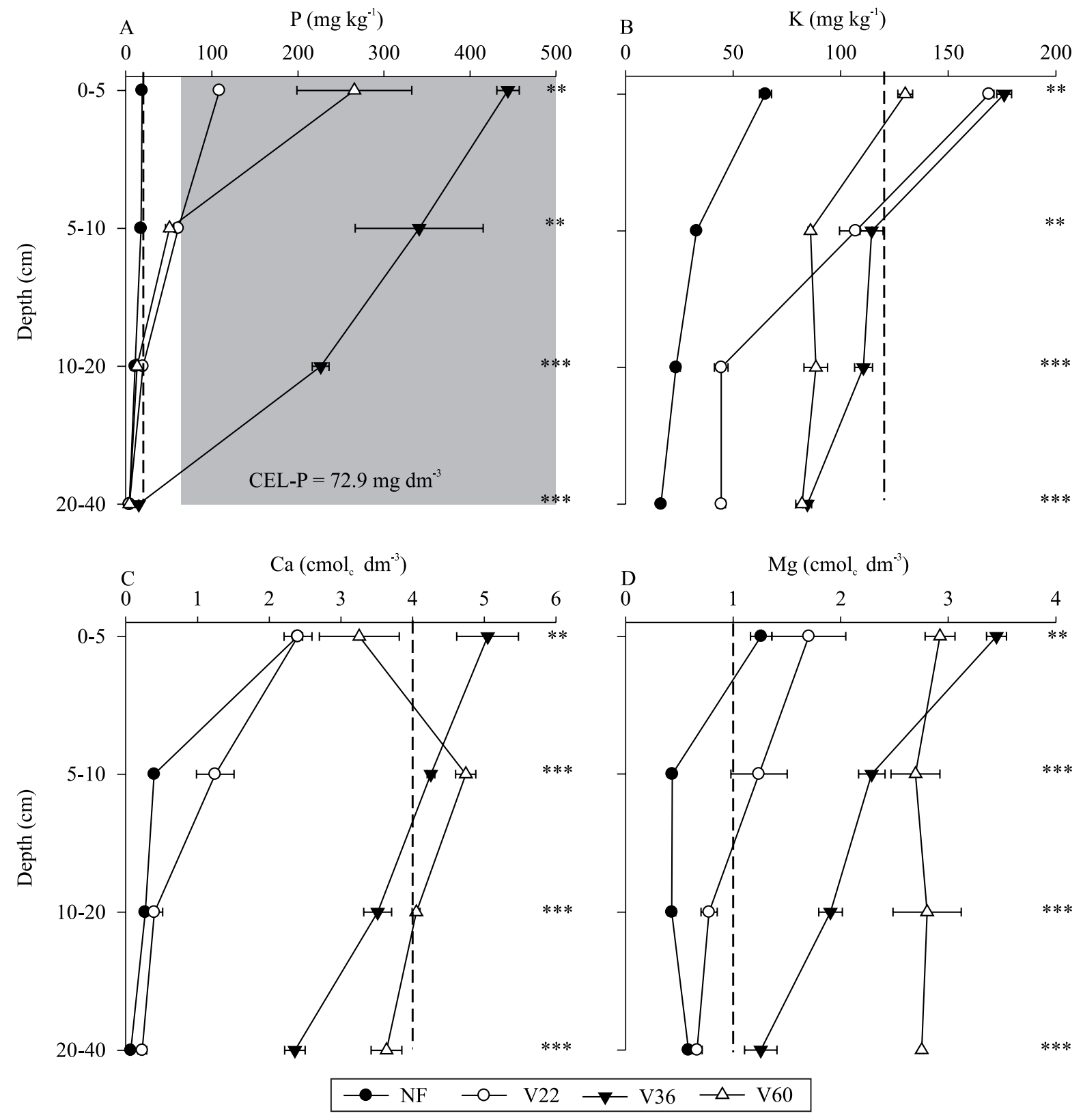

Figure 1. Available P (A) values with the respective critical environmental limit for $\mathrm{P}$ - CEL-P (gray area), available K (B), exchangeable $\mathrm{Ca}(\mathrm{C})$, and exchangeable $\mathrm{Mg}(\mathrm{D})$, in soils of vineyards and native forest area in the southern region of Santa Catarina state, Brazil. *,** and ***, significant at $5 \%, 1 \%$, and $0.1 \%$, respectively. The horizontal bars represent the standard error. The vertical dashed line indicates the critical level of $\mathrm{P}\left(18 \mathrm{mg} \mathrm{kg}^{-1}\right), \mathrm{K}\left(120 \mathrm{mg} \mathrm{kg}^{-1}\right), \mathrm{Ca}\left(4.0 \mathrm{cmol}_{\mathrm{c}} \mathrm{dm}^{-3}\right)$, and Mg $(1.0$ $\mathrm{cmol}_{\mathrm{c}} \mathrm{dm}^{-3}$ ), according to the Manual... (2016), for grapevines. NF, native forest; V22, 22-year-old vineyard; V36, 36-yearold vineyard; V60, 60-year-old vineyard. 
Manual... (2016), Ca contents were interpreted as low in NF and V22 $\left(<2.0 \mathrm{cmol}_{\mathrm{c}} \mathrm{dm}^{-3}\right)$, and high in V36 and $\mathrm{V} 60\left(>4.0 \mathrm{cmol}_{\mathrm{c}} \mathrm{dm}^{-3}\right)$, indicating that in V36 and V60 there is an adequate availability of $\mathrm{Ca}$ to grapes. In relation to $\mathrm{Mg}$, the NF area showed medium content $\left(0.5-1.0 \mathrm{cmol}_{\mathrm{c}} \mathrm{dm}^{-3}\right)$, while all vineyard areas showed high $\mathrm{Mg}$ content $\left(>1.0 \mathrm{cmol}_{\mathrm{c}} \mathrm{dm}^{-3}\right)$ that is suitable for grapes. The highest $\mathrm{Ca}$ and $\mathrm{Mg}$ contents observed at $20-40 \mathrm{~cm}$ soil depths of the V60 indicate the migration of limestone particles in the soil profile. Kaminski et al. (2005) evaluated the effect of the superficial and incorporated application of limestone on an Argissolo Vermelho (Alfisol). These authors drew attention to the fact that no-tillage of the soil favors the maintenance of the biopores and, consequently, the migration of fine particles of limestone, loading $\mathrm{Ca}$ and $\mathrm{Mg}$ to the deeper soil layers.

The highest SOM levels were observed at $0-5 \mathrm{~cm}$ soil depths in all areas; the V22 area showed the lowest SOM levels in comparison with the other areas (Figure 2). These results can be attributed to the addition of vegetal residue on the soil surface, that derived from the crop itself through the deposition of senescent leaves from branches pruned in the winter, also from the fall of fruit and, lastly, from the appearance of spontaneous plants and the use of cover plants, especially in the vineyard V36, which promoted a greater activity and microbial growth in the soil, increasing the C storage (Lange et al., 2015). The accumulation of SOM in the surface tends to increase with the no-tillage of the soil, contributing to the lower mineralization rate of the SOM, increasing the CEC values and the $\mathrm{Al}^{3+}$ complexation and, consequently, reducing the toxicity potential of this element. It is important to note that SOM is a source of $\mathrm{N}, \mathrm{P}$, and $\mathrm{S}$, from which a large part of $\mathrm{N}$ absorbed by grapes is derived from the mineralization of SOM, which justifies the maintenance of this element in the ecosystem in question (Brunetto et al., 2014).

The highest values of base saturation $(\mathrm{V} \%)$ in all soil layers were observed in cultivated areas, especially in the V60 (Table 3), mainly because this vineyard has the longest application history of limestone that is source of $\mathrm{Ca}$ and $\mathrm{Mg}$ (Raij, 2011). However, the lowest values of $\mathrm{V} \%$ in all layers were observed in NF and V22, most probably because of the lower history of $\mathrm{Ca}, \mathrm{Mg}$, and $\mathrm{K}$ source use, and because of the lower $\mathrm{pH}$ values that contribute with less adsorption of these nutrients due to the increase of positively dependent $\mathrm{pH}$ loadings on colloids (Goulding, 2016).

The values of $\mathrm{CEC}_{\mathrm{pH7.0}}$ ranged from 7.2 to 14.40 $\mathrm{cmol}_{\mathrm{c}} \mathrm{dm}^{-3}$, whose highest value was observed at 0-5 $\mathrm{cm}$ soil depths of the V36 area (Table 3). These highest $\mathrm{CEC}_{\mathrm{pH} 7.0}$ values in cultivated areas, especially up to $20 \mathrm{~cm}$ soil depth, are due to the increase of $\mathrm{pH}$ and SOM. As the $\mathrm{pH}$ increases, deprotonation occurs at the adsorption sites, with consequent release of the $\mathrm{H}^{+}$ ions, and increase of negative charges of the soil. The higher content of SOM also contributes to the increase of negative charges through the deprotonation and dissociation of $\mathrm{H}^{+}$from its functional groups, such as the carboxylic and phenolic ones (Sparks, 2003).

The highest available $\mathrm{Cu}$ contents were observed in the V36 and V60 areas, in the most superficial layers, while in V22 and NF there was no difference for $\mathrm{Cu}$ levels in depth (Figure $3 \mathrm{~A}$ ). These highest $\mathrm{Cu}$ levels with longer cultivation time can be attributed to the greater application history of fungicides containing

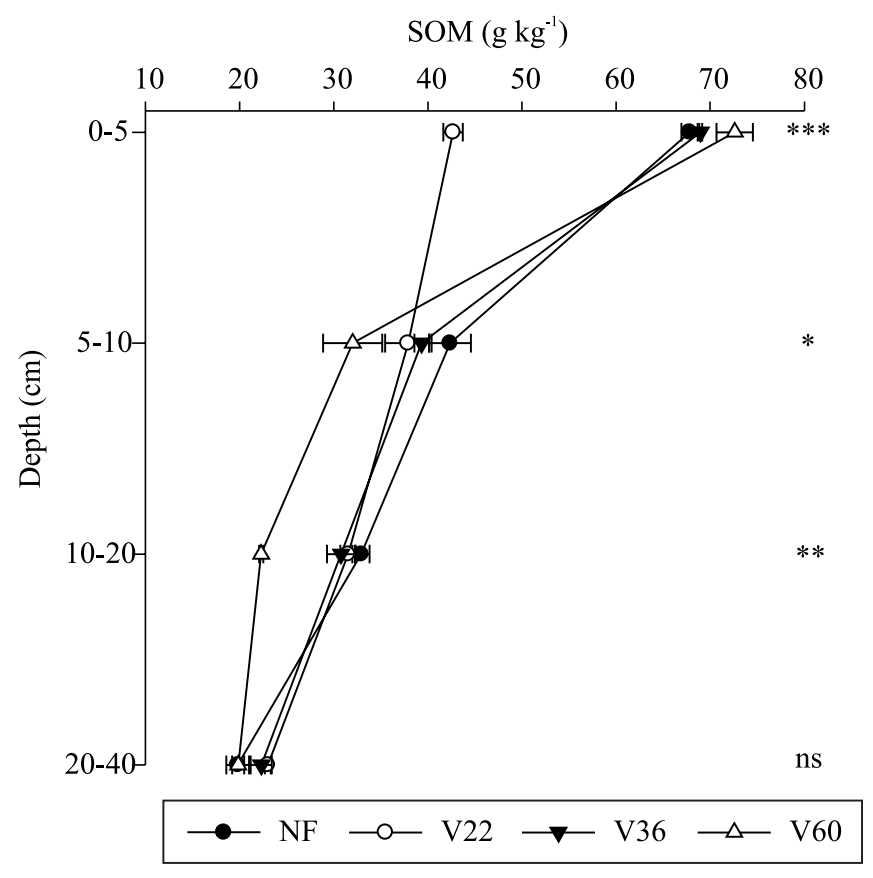

Figure 2. Soil organic matter content (SOM) in layers of vineyard and forest soils in the southern region of Santa Catarina state, Brazil. *Significant with p-value $\leq 0.05$ and $>0.01$; **Significant with $\mathrm{p}$-value $\leq 0.01$ and $>0.001$; $* * *$ Significant with value of $\mathrm{p} \leq 0.001$. ${ }^{\mathrm{n}}$ Nonsignificant. NF, native forest; V22, 22-year-old vineyard; V36, 36-year-old vineyard; V60, 60-year-old vineyard. 
$\mathrm{Cu}$ in their composition, for the preventive control of foliar fungal diseases (Casali et al., 2008). Part of the $\mathrm{Cu}$ applied can directly contact the soil because of the unidirectional way of the use, while part is deposited in the leaves and other organs of the aerial part, and due to precipitations, $\mathrm{Cu}$ can be washed to the ground. Moreover, $\mathrm{Cu}$ increment in the soil surface layers occurs because it has an empty "d" orbital and an electronic configuration [Ar] 3d104s1 (Casali et al., 2008) that gives high reactivity with the SOM functional groups,

Table 3. Base saturation (V\%) and cation exchange capacity (CEC) in vineyards and forest soils in the southern region of Santa Catarina state, Brazil ${ }^{(1)}$.

\begin{tabular}{|c|c|c|c|c|c|}
\hline \multirow{2}{*}{$\begin{array}{l}\text { Soil depths } \\
\text { (cm) }\end{array}$} & \multicolumn{4}{|c|}{ Vineyard and native forest soils } & \multirow{2}{*}{$\begin{array}{l}\text { CV } \\
(\%)\end{array}$} \\
\hline & NF & V22 & V36 & V60 & \\
\hline \multicolumn{6}{|c|}{ Base saturation (V\%) } \\
\hline $0-5$ & $40.34 \mathrm{aC}$ & $53.33 \mathrm{aB}$ & $65.13 \mathrm{aA}$ & $63.06 \mathrm{aA}$ & 6.82 \\
\hline $5-10$ & $9.69 \mathrm{bC}$ & $20.22 \mathrm{bC}$ & $55.37 \mathrm{bB}$ & $71.13 \mathrm{aA}$ & 12.85 \\
\hline $10-20$ & $10.00 \mathrm{bC}$ & $9.79 \mathrm{bC}$ & $53.92 \mathrm{bB}$ & $71.14 \mathrm{aA}$ & 9.03 \\
\hline $20-40$ & $9.26 \mathrm{bC}$ & $7.46 \mathrm{bC}$ & $45.95 \mathrm{cB}$ & $67.10 \mathrm{aA}$ & 5.88 \\
\hline CV (\%) & 9.06 & 24.94 & 4.46 & 5.24 & - \\
\hline \multicolumn{6}{|c|}{$\mathrm{CEC}_{\mathrm{PH} 7.0}\left(\mathrm{cmol}_{\mathrm{c}} \mathrm{dm}^{-3}\right)$} \\
\hline $0-5$ & $9.48 \mathrm{bA}$ & $8.84 \mathrm{bA}$ & $14.40 \mathrm{aA}$ & $9.91 \mathrm{bA}$ & 7.16 \\
\hline $5-10$ & $9.41 \mathrm{bA}$ & $12.99 \mathrm{aA}$ & $12.35 \mathrm{aB}$ & $10.93 \mathrm{baA}$ & 7.02 \\
\hline $10-20$ & $7.63 \mathrm{bB}$ & $14.04 \mathrm{aA}$ & $10.83 \mathrm{baC}$ & $9.94 \mathrm{baA}$ & 20.63 \\
\hline $20-40$ & $7.52 \mathrm{cB}$ & $14.23 \mathrm{aA}$ & $8.51 \mathrm{cbD}$ & $10.13 \mathrm{bA}$ & 7.19 \\
\hline $\mathrm{CV}(\%)$ & 5.04 & 19.32 & 4.36 & 4.91 & - \\
\hline
\end{tabular}

${ }^{(1)}$ Means followed by equal letters, lowercases in the column and uppercases in the row, do not differ by Tukey's test, at $5 \%$ probability. NF, native forest area; V22, 22-year-old vineyard; V36, 36-year-old vineyard; V60, 60-year-old vineyard.

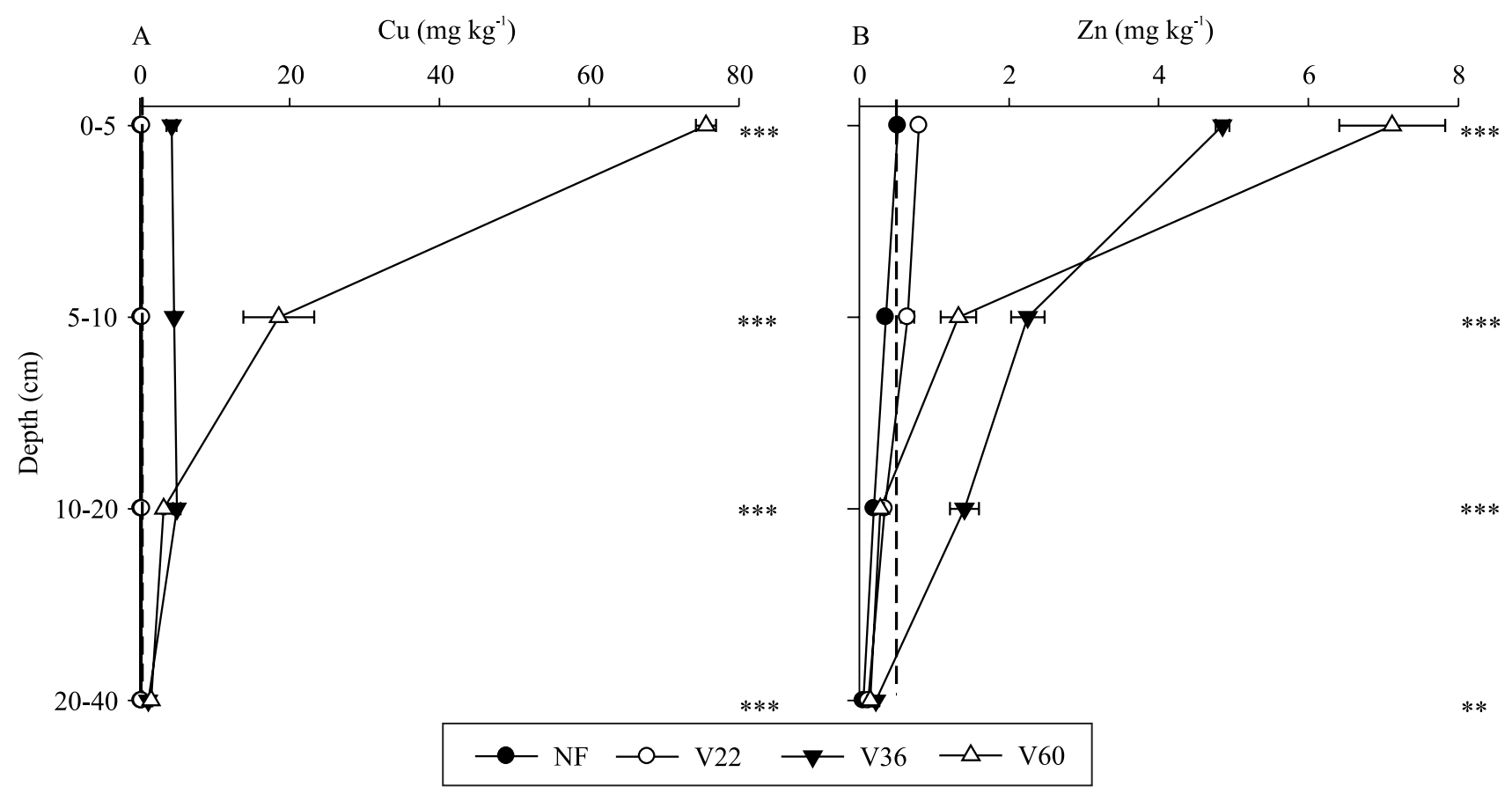

Figure 3. $\mathrm{Cu}(\mathrm{A})$ and $\mathrm{Zn}(\mathrm{B})$ contents extracted by Mehlich-1 from soils with vineyards and forest, in the southern region of Santa Catarina state, Brazil. *, **, and ***Significant at 5\%,1\%, and $0.1 \%$, respectively. The horizontal bars represent the standard error. The vertical dashed line indicates the critical level of $\mathrm{Cu}\left(0.4 \mathrm{mg} \mathrm{kg}^{-1}\right)$ and $\mathrm{Zn}\left(0.5 \mathrm{mg} \mathrm{kg}^{-1}\right)$, according to the Manual... (2016), for grapevines. NF, native forest; V22, 22-year-old vineyard; V36, 36-year-old vineyard; V60, 60-year-old vineyard. 
decreasing their mobility in the profile (Brunetto et al., 2014). However, it is possible to observe that there was a migration of $\mathrm{Cu}$ in the soil profile in V60 that may have occurred because of the saturation of the adsorption sites of reactive particles in the surface layer. This migration entangles the formation of stable metal complexes with the functional groups of SOM and clay minerals (Couto et al., 2015).

The highest $\mathrm{Zn}$ contents were observed at $0-5 \mathrm{~cm}$ soil depths in the V60, and at 5-10 and 10-20 cm soil depths in the V36, and did not differ between the areas at 20-40 cm soil depths (Figure 3 B). The higher Zn levels in the V60 are probably due to the use of fungicides that have this element in their compositions, such as mancozeb. These $\mathrm{Zn}$ levels can also be attributed to organic residue deposited on the soil, or even mineral fertilizers that have $\mathrm{Zn}$ in their compositions and may have contributed to the observed increases. It should be stressed that the $\mathrm{Zn}$ migration to depth may have occurred due to the increase of $\mathrm{Cu}$ on the surface, since $\mathrm{Cu}$ adsorption affinity with functional groups of organic and inorganic particles is higher than that of $\mathrm{Zn}$ (Brunetto et al., 2014). Consequently, there is a competition between $\mathrm{Cu}$ and $\mathrm{Zn}$, stimulating a desorption, followed by migration in the soil profile through the descending flow of the solution (Tiecher et al., 2016). In addition, as already observed by Tiecher et al. (2016) on vines and soil cover plants, the increment of these metals on the soil surface, especially in the sandy ones, which have low adsorption capacity of the two metals, can stimulate the potential for toxicity to plants.

Therefore, the high P levels available in the soils of the vineyard areas are due to excess phosphate fertilization and to the prolonged use of fungicides, which contain metallic elements that are responsible for the high $\mathrm{Cu}$ and $\mathrm{Zn}$ levels.

\section{Conclusions}

1. The vineyards in the southern region of Santa Catarina state show changes in the soil chemical properties with time and P levels above the CEL-P, at least in one of the soil layers.

2. There is an increase of $\mathrm{pH}$ values, in the levels of $\mathrm{P}, \mathrm{K}, \mathrm{Ca}, \mathrm{Mg}, \mathrm{Cu}, \mathrm{Zn}, \mathrm{SOM}$ and base saturation, and a reduction of $\mathrm{Al}$ saturation, with the most accentuated effects in the vineyard areas with the longest cultivation time.

\section{References}

BRUNETTO, G.; CERETTA, C.A.; MELO, G.W.B. de; KAMINSKI, J.; TRENTIN, G.; GIROTTO, E.; FERREIRA, P.A.A.; MIOTTO, A.; TRIVELIN, P.C.O. Contribution of nitrogen from agricultural residues of rye to 'Niagara Rosada' grape nutrition. Scientia Horticulturae, v.169, p.66-70, 2014. DOI: https://doi.org/10.1016/j.scienta.2014.02.019.

BRUNETTO, G.; FERREIRA, P.A.A.; MELO, G.W.; CERETTA, C.A.; TOSELLI, M. Heavy metals in vineyards and orchard soils. Revista Brasileira de Fruticultura, v.39, e-263, 2017. DOI: https://doi.org/10.1590/0100-29452017263.

CASALI, C.A.; MOTERLE, D.F.; RHEINHEIMER, D. dos S.; BRUNETTO, G.; CORCINI, A.L.M.; KAMINSKI, J.; MELO, G.W.B. de. Formas e dessorção de cobre em solos cultivados com videira na Serra Gaúcha do Rio Grande do Sul. Revista Brasileira de Ciência do Solo, v.32, p.1479-1487, 2008. DOI: https://doi.org/10.1590/S0100-06832008000400012.

CIOTTA, M.N.; CERETTA, C.A.; SILVA, L.O.S. da.; FERREIRA, P.A.A.; SAUTTER, C.K.; COUTO, R. da R.; BRUNETTO, G. Grape yield, and must compounds of "Cabernet Sauvignon" grapevine in sandy with potassium contents increasing. Ciência Rural, v.46, p.1376-1383, 2016. DOI: https://doi.org/10.1590/0103-8478cr20150472.

CLAESSEN, M.E.C. (Org.). Manual de métodos de análise de solo. 2.ed. rev. e atual. Rio de Janeiro: Embrapa-CNPS, 1997. (EMBRAPA-CNPS. Documentos, 1).

COUTO, R.R.; BENEDET, L.; COMIN, J.J.; BELLI FILHO, P.; MARTINS, S.R.; GATIBONI, L.C.; RADETSKI, M.; VALOIS, C.M.; AMBROSINI, V.G.; BRUNETTO, G. Accumulation of copper and zinc fractions in vineyard soil in the mid-western region of Santa Catarina, Brazil. Environmental Earth Sciences, v.73, p.6379-6386, 2015. DOI: https://doi.org/10.1007/s12665-014-3861-x.

GATIBONI, L.C.; SMYTH, T.J.; SCHMITT, D.E.; CASSOL, P.C.; OLIVEIRA, C.M.B. de. Proposta de limites críticos ambientais de fósforo para solos de Santa Catarina. Lages: UDESC/CAV, 2014. (Boletim técnico, 2).

GIROTTO,E.; CERETTA, C.A.; LOURENZI, C.R.; LORENSINI, F.; TIECHER, T.L.; VIEIRA, R.C.B.; TRENTIN, G.; BASSO, C.J.; MIOTTO, A.; BRUNETTO, G. Nutrient transfers by leaching in a notillage system through soil treated with repeated pig slurry applications. Nutrient Cycling Agroecosystems, v.95, p.115131, 2013. DOI: https://doi.org/10.1007/s1070501395522.

GIROTTO, E.; CERETTA, C.A.; ROSSATO, L.V.; FARIAS, J.G.; BRUNETTO, G.; MIOTTO, A.; TIECHER, T.L.; CONTI, L. de; LOURENZI, C.R.; SCHMATZ, R.; GIACHINI, A.; NICOLOSO, F.T. Biochemical changes in black oat (Avena strigosa Schreb) cultivated in vineyard soils contaminated with copper. Plant Physiology and Biochemistry, v.103, p.199-207, 2016. DOI: https://doi.org/10.1016/j.plaphy.2016.02.030.

GOULDING, K.W.T. Soil acidification and the importance of liming agricultural soils with particular reference to the United Kingdom. Soil Use and Management, v.32, p.390-399, 2016. DOI: https://doi.org/10.1111/sum.12270. 
KAMINSKI， J.; SANTOS， D.R. dos; GATIBONI， L.C.; BRUNETTO, G.; SILVA, L.S. da. Eficiência da calagem superficial e incorporada precedendo o sistema plantio direto em um Argissolo sob pastagem natural. Revista Brasileira de Ciência do Solo, v.29, p.573-580, 2005. DOI: https://doi.org/10.1590/S0100-06832005000400010.

LANGE, M.; EISENHAUER, N.; SIERRA, C.A; BESSLER, H.; ENGELS, C.; GRIFFITHS, R.I.; MELLADO-VÁZQUEZ, P.G.; MALIK, A.A.; ROY, J.; SCHEU, S.; STEINBEISS, S.; THOMSON, B.C.; TRUMBORE, S.E.; GLEIXNER, GERD. Plant diversity increases soil microbial activity and soil carbon storage. Nature Communications, v.6, art.6707, 2015. DOI: https://doi.org/10.1038/ncomms7707.

LEHMANN, D.H.; CASSOL, P.C.; SACOMORI, W.; TEIXEIRA, A.K.F.; MAFRA, A.L.; ERNANI, P.R.; ZALAMENA, J. Cobertura do solo em vinhedos modifica os atributos do solo e o estado nutricional das videiras. Revista de Ciências Agroveterinárias, v.15, p.198-207, 2016. DOI: https://doi.org/10.5965/223811711532016198.

LOURENZI， C.R.; CERETTA， C.A.; TIECHER， T.L.; LORENSINI, F.; CANCIAN, A.; STEFANELLO, L.; GIROTTO, E.; VIEIRA, R.C.B.; FERREIRA, P.A.A.; BRUNETTO, G. Forms of phosphorus transfer in runoff under no-tillage in a soil treated with successive swine effluents applications. Environmental Monitoring and Assessment, v.187, art.209, 2015. DOI: https://doi.org/10.1007/s10661-015-4437-2.

MANUAL de calagem e adubação para os Estados do Rio Grande do Sul e de Santa Catarina. 11.ed. [S.1.]: Comissão de Química e Fertilidade do Solo, RS/SC, 2016. 375p.

MCBRIDE, M.B. Environmental chemistry of soils. New York: Oxford University Press, 1994. 406p.

MURPHY, J.; RILEY, J.P. A single solution method for the determination of soluble phosphate in sea water. Journal of the Marine Biological Association of the United Kingdom, v.37, p.9-14, 1958. DOI: https://doi.org/10.1017/S0025315400014776.

PAUSTIAN, K.; LEHMANN, J.; OGLE, S.; REAY, D.; ROBERTSON, G.P.; SMITH, P. Climate-smart soils. Nature, v.532, p.49-57, 2016. DOI: https://doi.org/10.1038/nature17174.

PRIORI, S.; D'AVINO, L.; AGNELLI, A.E.; VALBOA, G.; KNAPIČ, M.; CHROERS, H.-J.; AKCA, E.; TANGOLAR, S.; KIRAZ, M.E.; GIFFARD, B.; FULCHIN, E. Effect of organic treatments on soil carbon and nitrogen dynamics in vineyard. EQA - International Journal of Environmental Quality, v.31, p.110, 2018. DOI: https://doi.org/10.6092/issn.2281-4485/7896.

RAIJ, B. van. Fertilidade do solo e manejo de nutrientes. Piracicaba: IPNI, 2011. 420 p.

SANTOS, H.G. dos; JACOMINE, P.K.T.; ANJOS, L.H.C. dos; OLIVEIRA, V.Á. de; LUMBRERAS, J.F.; COELHO, M.R.; ALMEIDA, J.A. de; ARAÚJO FILHO, J.C. de; OLIVEIRA, J.B. de; CUNHA, T.J.F. Sistema Brasileiro de Classificação de Solos. 5.ed. rev. e ampl. Brasília: Embrapa, 2018.
SCHMITT, D.E.; GATIBONI, L.C.; GIROTTO, E.; LORENSINI, F.; MELO, G.W.B.; BRUNETTO, G. Phosphorus fractions in the vineyard soil of the Serra Gaúcha of Rio Grande do Sul, Brazil. Revista Brasileira de Engenharia Agrícola e Ambiental, v.18, p.134-140, 2014. DOI: https://doi.org/10.1590/S1415-43662014000200002.

SHARPLEY, A. Managing agricultural phosphorus to minimize water quality impacts. Scientia Agricola, v.73, p.1-8, 2016. DOI: https://oi.org/10.1590/0103-9016-2015-0107.

SOIL SURVEY STAFF. Soil taxonomy: a basic system of soil classification for making and interpreting soil survey. $2^{\text {nd }}$ ed. Washington: USDA, NRCS, 1999. 866p.

SPARKS, D.L. Environmental Soil Chemistry. $2^{\text {nd }}$ ed. San Diego: Academic Press, 2003. DOI: https://oi.org/10.1016/ B978-0-12-656446-4.X5000-2.

TECCHIO, M.A.; PAIOLLI-PIRES, E.J.; TERRA, M.M.; TEIXEIRA, L.A.J.; LEONEL, S. Características físicas e acúmulo de nutrientes pelos cachos de 'Niagara Rosada' em vinhedos na região de Jundiaí. Revista Brasileira de Fruticultura, v.29, p.621-625, 2007. DOI: https://doi.org/10.1590/ S0100-29452007000300038.

TEDESCO, M.J.; GIANELLO, C.; BISSANI, C.A.; BOHNEN, H.; VOLKWEISS, S.J. Análise de solo, plantas e outros materiais. 2.ed. rev. e ampl. Porto Alegre: Universidade Federal do Rio Grande do Sul, 1995. 174p. (Boletim técnico, 5).

TIECHER, T.L.; CERETTA, C.A.; FERREIRA, P.A.A.; LOURENZI, C.R.; TIECHER, T.; GIROTTO, E.; NICOLOSO, F.T.; SORIANI, H.H.; DE CONTI, L.; MIMMO, T.; CESCO, S.; BRUNETTO, G. The potential of Zea mays L. in remediating copper and zinc contaminated soils for grapevine production. Geoderma, v.262, p.52-61, 2016. DOI: https://doi.org/10.1016/j. geoderma.2015.08.015.

TIECHER, T.L.; TIECHER, T.; CERETTA, C.A.; FERREIRA, P.A.A.; NICOLOSO, F.T.; SORIANI, H.H.; DE CONTI, L.; KULMANN, M.S.S.; SCHNEIDER, R.O.; BRUNETTO, G. Tolerance and translocation of heavy metals in young grapevine (Vitis vinifera) grown in sandy acidic soil with interaction of high doses of copper and zinc. Scientia Horticulturae, v.222, p.203212, 2017. DOI: https://doi.org/10.1016/j.scienta.2017.05.026.

TOKURA, A.M.; FURTINI NETO, A.E.; CARNEIRO, L.F.; CURI, N.; SANTOS, J.Z.L.; ALOVISI, A.A. Dinâmica das formas de fósforo em solos de textura e mineralogia contrastantes cultivados com arroz. Acta Scientiarum. Agronomy, v.33, p.171179, 2011. DOI: https://doi.org/10.4025/actasciagron.v33i1.1435.

VIEIRA, F.C.B.; HE, Z.L.; WILSON, C.; BAYER, C. Speciation of aluminum in solution of an acidic sandy soil amended with organic composts. Communications in Soil Science and Plant Analysis, v.40, p.2094-2110, 2009. DOI: https://doi.org/10.1080/00103620902960617. 